\title{
Behaviour of Fungi Antagonistic to Sclerotinia sclerotiorum on Plant Tissue Segments
}

\author{
By JOHN M. WHIPPS \\ Glasshouse Crops Research Institute, Littlehampton, West Sussex BNI7 6LP, UK
}

(Received 14 October 1986; revised 2 February 1987)

\begin{abstract}
To assess the ability of fungi antagonistic to Sclerotinia sclerotiorum to inhibit the formation of sclerotia and to grow through plant tissue from cut surfaces, a plant-tissue-based system has been developed using celery, lettuce and tomato segments. Pythium oligandrum consistently showed no ability to grow through plant tissue or prevent sclerotium formation whereas Gliocladium roseum and three isolates of Trichoderma harzianum showed significant ability to grow through plant tissue and significantly decreased the production of sclerotia. Treatment of the plant tissue with $G$. roseum or $T$. harzianum $24 \mathrm{~h}$ before, or at the same time as, application of $S$. sclerotiorum gave significantly greater inhibition of sclerotium formation than did treatment $24 \mathrm{~h}$ after application of $S$. sclerotiorum. Of the fungi tested, $G$. roseum had the greatest ability to grow through the tissue and $T$. harzianum WT6 the greatest ability to inhibit sclerotium formation.
\end{abstract}

\section{INTRODUCTION}

Most systems for the biological control of soil-borne plant pathogens involve incorporation of propagules of an antagonistic micro-organism into the soil or onto the surface of seeds or plant tissue transplants in an attempt to decrease populations of pathogens or inhibit their growth before contact with the plant (e.g. Suslow \& Schroth, 1982; Hubbard et al., 1983; Van den Boogert \& Jager, 1984; Lewis \& Papavizas, 1985; Loper et al., 1985; Fravel et al., 1985 and references therein). These systems have had varying rates of success. However, one of the most successful and routinely used systems for biocontrol consists of inoculation of stumps of pine with Phlebia ((Peniophora) gigantea to control heart-rot caused by Heterobasidion annosum (Fomes annosus) (Rishbeth, 1975). Here, no attempt is made to control the pathogen in the soil, but by precolonization of the dead stump with $P$. gigantea the pathogen is excluded from a potential source of food. Such a treatment could be of use in other agricultural and horticultural situations. For instance, in the glasshouse after harvest of lettuce and celery considerable quantities of crop debris are present. Under good horticultural practice this debris is removed but often the cut stumps and roots are incorporated to increase the organic matter content of the soil. If, however, some of this material is infected with Sclerotinia sclerotiorum, disease carryover can be encouraged by this procedure. In the field, techniques other than debris removal are sometimes used to lessen disease carryover. For example, the availability of food bases for sclerotium formation may be decreased by spraying the debris with contact herbicides immediately after harvest and cycles of soil flooding can be used to diminish survival of sclerotia (Coley-Smith \& Cooke, 1971). Irrespective of these treatments, the incidence of disease caused by pathogens such as $S$. sclerotiorum builds up with time, necessitating soil sterilization by steam or chemical treatment such as methyl bromide (Lynch \& Ebben, 1986). A possible novel approach to the control of such pathogens would be to inoculate the residues at harvest with a fungus which has both the capability of entering plant tissues at cut surfaces (so that the residues become occupied by the inoculated fungus) and antagonistic properties towards pathogens. Thus, an ideal inoculant would outcompete pathogens already in occupation of infected residues but would also be able to use the residues as a food base after incorporation from which to grow into the soil and decrease populations of pathogens there. 
As a prerequisite to glasshouse experiments some plant-tissue-based tests have been carried out and the results of these are reported here. They were designed firstly to see if a plant-tissuebased system could be used as an indicator of the ability of different antagonistic fungi to prevent formation of sclerotia of $S$. sclerotiorum, and secondly to determine the capability of the antagonists to infect plant tissue from cut surfaces. The study included tomato as well as lettuce and celery to see if the interactions were similar in a range of different plant tissues likely to be found in the glasshouse.

\section{METHODS}

Fungal and plant material. The pathogen, Sclerotinia sclerotiorum Lib. (de Bary), was isolated from a sclerotium obtained from glasshouse soil under routine cropping with lettuce and celery. The antagonists used were Pythium oligandrum Dreschler (IMI 133857), a well-documented mycoparasite (Dreschler, 1943; Deacon, 1976; Lutchmeah \& Cooke, 1984; Veselý \& Hejdánek, 1984), Gliocladium roseum (Link) Bain (IMI 300400) obtained from the same glasshouse soil as S. sclerotiorum, and three isolates of Trichoderma harzianum Rifai - IMI 275950, isolated from straw (Harper \& Lynch, 1984), WT-6 (from G. C. Papavizas, Beltsville, Md, USA) and IMI 298374, isolated from baited hyphae of Rhizoctonia solani. In preliminary tests on a range of agars all antagonists were shown to be capable of parasitizing mycelium of $S$. sclerotionum directly; $G$. roseum and all strains of $T$. harzianum were also able to produce metabolites that inhibited normal growth of $S$. sclerotiorum. All fungi were maintained on potato dextrose agar (PDA) (Oxoid) at $18^{\circ} \mathrm{C}$. For experiments, agar plugs $(1 \mathrm{~cm}$ diameter) were taken from the growing margin of all fungi.

Plants of tomato (Lycopersicum esculentum Mill., cv. Moneymaker), lettuce (Lactuca sativa L., cv. Ostinata) and celery (Apium graveolens L., cv. Celebrity) were grown in pots in the glasshouse at $18-25^{\circ} \mathrm{C}$. The tomatoes were grown until $40-60 \mathrm{~cm}$ tall and the lettuce and celery until market sized.

The tissue system. Tomato stem from the first to the seventh leaf was cut into $2 \mathrm{~cm}$ lengths with a sterile razor blade and the pieces were randomized in sterile $15 \mathrm{~cm}$ Petri dishes. All operations were then carried out under clean but not sterile conditions. Three $2 \mathrm{~cm}$ segments were placed on moist $7 \mathrm{~cm}$ filter paper in a $9 \mathrm{~cm}$ diameter Petri dish and arranged around a PDA plug containing either an antagonist (treatment $\mathrm{A}$ ), a plug of antagonist on top of a plug of $S$. sclerotiorum (treatment B) or a plug of $S$. sclerotiorum (treatment C), with the cut ends of the segments touching the plugs of agar (Fig. 1). The agar plugs were always placed in the Petri dishes with the upper surface facing upwards. Each treatment was replicated three times. The plates were then placed in a controlledenvironment plant growth room at $18{ }^{\circ} \mathrm{C}$ with a $14 \mathrm{~h}$ daylength with an irradiance of $25 \mathrm{~W} \mathrm{~m}^{-2}$ from a bank of $65 / 80 \mathrm{~W}$ white fluorescent tubes. After $24 \mathrm{~h}$, treatment A received a plug of $S$. sclerotiorum and treatment $\mathrm{C}$ a plug of antagonist. The plates were observed every day for fungal growth and sclerotium formation and the filter papers kept moist with sterile distilled water for $14 \mathrm{~d}$; the watering was then stopped. After $28 \mathrm{~d}$ the sclerotia that had formed on the tissue and those that had formed on the surface of the Petri plate were separated, counted and weighed. The tissue segments were sampled for the presence of antagonist at the distal end of the tissue relative to the agar plug. The distal surface $(1-2 \mathrm{~mm})$ of the tissue segment was removed with a sterile scalpel and tissue blocks $(2 \times 2 \times 2 \mathrm{~mm})$ were taken from within the segment and directly plated onto PDA $+2 \mu \mathrm{g}$ aureomycin $\mathrm{ml}^{-1}$ to assess general fungal colonization, V8 juice medium (Papavizas \& Lumsden, 1982) for specific isolation of Trichoderma spp., or cornmeal agar (Oxoid) for detection of $P$. oligandrum.

Similar treatments were carried out for lettuce mid-rib, obtained from leaves $14-20 \mathrm{~cm}$ in length, and celery petioles, obtained from between $2 \mathrm{~cm}$ from the base to below the lamina expansion point. Outer or centre leaves or petioles for lettuce and celery respectively were not used.

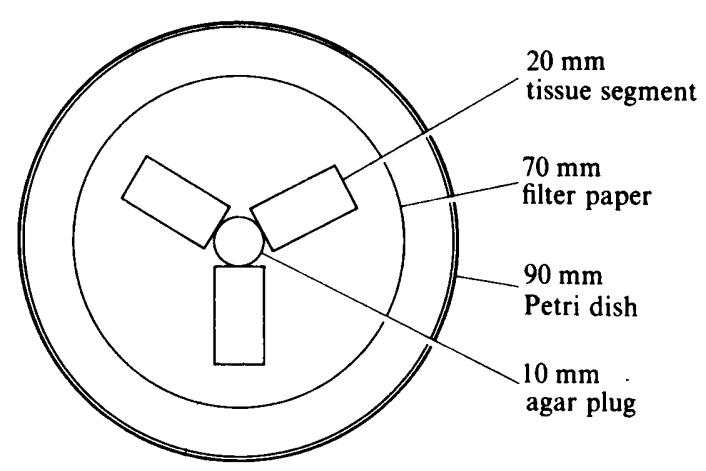

Fig. 1. Arrangement of tissue segments in a Petri dish. 
Statistical analysis. Data were analysed by generalized linear model methods. In the case of binary (presence/absence) data a binomial error function with logit link was used, while the count data were analysed using a log-linear model:Poisson error function with log link (McCullagh \& Nelder, 1983).

\section{RESULTS}

\section{Effect of antagonists on production of sclerotia}

The overall pattern of antagonist effect was similar for both number and weight of sclerotia produced and so for clarity the data for number of sclerotia only are given in Table 1. A comparison was made between the numbers of sclerotia produced with the pathogen alone (control) and the numbers produced with the antagonist present for each of the five antagonists

Table 1. Mean number of sclerotia produced per Petri plate and significance of effect of antagonist and time of application

$\overbrace{\begin{array}{c}\text { Mean no. of } \\ \text { sclerotia }\end{array}}^{\text {Treatmentł: }} \overbrace{\begin{array}{c}\text { Control v. } \\ \text { Significance } \\ \text { of differences } \S\end{array}}^{\text {Tissuet } \overbrace{\text { Between }}^{\text {Beatments }}}$

\begin{tabular}{|c|c|c|}
\hline \multicolumn{3}{|c|}{ Plate† } \\
\hline $\begin{array}{l}\text { Mean no. of } \\
\text { sclerotia }\end{array}$ & $\begin{array}{l}\text { Sign } \\
\text { of dif }\end{array}$ & $\begin{array}{l}\text { cance } \\
\text { ences§ }\end{array}$ \\
\hline Treatment $f:$ & Control v. & Betw \\
\hline
\end{tabular}

\section{Celery}

Control/

G. roseum

$12 \cdot 3$

T. harzianum

IMI 298374

T. harzianum

IMI 275950

T. harzianum WT6

Lettuce

Control

$P$. oligandrum

$G$. roseum

$T$. harzianum

IMI 298374

$T$. harzianum

IMI 275950

T. harzianum

WT6

Tomato

Control

$P$. oligandrum

NS
$* * *$
$* * *$
$* * *$

$\begin{array}{lll}1.0 & 0 & 5.7\end{array}$

$\begin{array}{lll}1.0 & 0 & 5.7 \\ 0 & 0 & 1.7\end{array}$

reatments

NS
$* *$
$* * *^{b}$
$* *^{b}$

$5 \cdot 3$

$\begin{array}{lllll}13.0 & 17.0 & 14.7 & \mathrm{NS} & \mathrm{NS}^{a}\end{array}$

$\begin{array}{ccccc}0 & 0 & 0 & - & - \\ 0 & 0 & 0.7 & - & -\end{array}$

$\begin{array}{lllll}0 & 0 & 1.7 & * * & \text { NS }^{a b}\end{array}$

$0 \quad 0 \quad 0$

$6 \cdot 7$

$\begin{array}{lllll}3.0 & 4.3 & 2.0 & \text { NS } & \text { NS }\end{array}$

$\begin{array}{lllll}0.7 & 0 & 0.7 & * * * & N^{b}\end{array}$

$0 \quad 0 \quad 1.0 \quad * * * \quad * b$

$\begin{array}{llll}*^{b} & 0.7 & 0 & 0.7 \\ \text { NS }^{b} & 0 & 0 & 1.0\end{array}$

$\begin{array}{llllll}* b & 0 & 0 & 0.7 & * * * & \text { NS }^{b}\end{array}$

$\begin{array}{cccccccccc}0 & 0 & 2 \cdot 0 & * * * & * b & 0 & 0 & 0.7 & * * * & \text { NS }^{b} \\ 0 & 0 & 0 & - & - & 0 & 0 & 0 & -\end{array}$

$G$. roseum

$19 \cdot 0$

$\begin{array}{lll}16.0 & 8.0 & 10.7\end{array}$

$\begin{array}{lll}0 & 0.3 & 6.3\end{array}$

$T$. harzianum

IMI 298374

$T$. harzianum

IMI 275950

$T$. harzianum $\begin{array}{lll}2.0 & 2.0 & 5.3\end{array}$

$\begin{array}{lll}4.3 & 0.3 & 6.7\end{array}$

$\begin{array}{lll}0 & 0 & 9.3\end{array}$
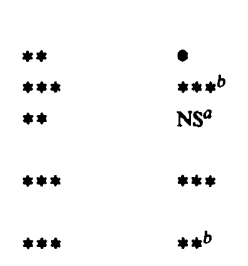

$29 \cdot 7$

$\begin{array}{lllll}27.0 & 26.0 & 25 \cdot 7 & \text { NS } & \text { NS }^{a}\end{array}$

$\begin{array}{llll}0 & 0 & 14.3 & * * \quad * a b\end{array}$

$0 \quad 0 \quad 2 \cdot 0 \quad * * * \quad * b$

$0 \quad 0 \quad 18.6 \quad * * *$

WT6

+ On any Petri plate sclerotia could be produced on the plant tissue alone or on the plant tissue and the surface of the Petri plate.

‡ Treatments A, B and C have antagonist applied $24 \mathrm{~h}$ before, simultaneously with, or $24 \mathrm{~h}$ after $S$. sclerotiorum respectively.

$\S$ Effects are not significant (NS) or significant at the $5 \%(*), 1 \%(* *)$ or $0 \cdot 1 \%(* *)$ level respectively. No test $(-)$ is possible with large numbers of zero values. Superscript letters indicate the following: $a$, variation between pieces within dishes was much greater than expectation; $b$, analyses suspect due to large number of zero values.

$\|$ The comparison is for control $v$. mean of treatments $A, B$ and $C$.

I $S$. sclerotiorum alone. 
Table 2. Incidence of sclerotia on tissue

(a) Effect of antagonist

Incidence of sclerotia (out of 27)

\begin{tabular}{|c|c|c|c|c|c|c|}
\hline & \multirow[b]{2}{*}{ P. oligandrum } & \multirow[b]{2}{*}{$G$. roseum } & \multicolumn{3}{|c|}{ T. harzianum } & \multirow{2}{*}{$\begin{array}{c}\text { Significance } \\
\text { of differences } \\
\text { between } \\
\text { antagonists } \dagger\end{array}$} \\
\hline & & & IMI 298374 & IMI 275950 & WT6 & \\
\hline Celery & 27 & 23 & 13 & 6 & 4 & $* * *$ \\
\hline $\begin{array}{l}\text { Lettuce } \\
\text { Tomato }\end{array}$ & $\begin{array}{l}23 \\
27\end{array}$ & $\begin{array}{r}8 \\
10\end{array}$ & $\begin{array}{r}5 \\
13\end{array}$ & $\begin{array}{r}6 \\
17\end{array}$ & $\begin{array}{l}0 \\
9\end{array}$ & $\begin{array}{l}* * * \\
* * *\end{array}$ \\
\hline
\end{tabular}

SE range $1 \cdot 85-2 \cdot 60 \ddagger$

(b) Effect of time of application Incidence of sclerotia (out of 45)

$\begin{array}{llccc}\text { A Incidence of sclerotia (out of 45) } & \text { C } & \begin{array}{c}\text { Significance } \\ \text { of differences } \\ \text { between treatments } \dagger\end{array} \\ \text { Celery } & 21 & 17 & 35 & * * * \\ \text { Lettuce } & 12 & 8 & 22 & * * * \\ \text { Tomato } & 18 & 13 & 35 & * *\end{array}$

$\dagger * * *$, effect significant at the $0 \cdot 1 \%$ level.

$\ddagger$ SEs under a binomial hypothesis vary depending on the score according to the formula $r(n-r) / n$ where $r$ is the score (out of $n$ ). Note that the SE is 0.0 for scores of 0 and $n$.

$\S$ Treatments A, B and C have antagonist applied $24 \mathrm{~h}$ after $S$. sclerotiorum respectively.

separately as well as a comparison of the number of sclerotia produced at different times of antagonist application. Each comparison was made using a log-linear model (analysis of count data) and it should be noted that the analyses are not independent inasmuch as the control was included in all of them for each tissue. $P$. oligandrum had no effect on the number of sclerotia produced on celery or lettuce tissue but did significantly reduce the number produced on tomato tissue. It had no effect on the number of sclerotia produced on the plate. All the other antagonists significantly reduced the number of sclerotia produced on all tissues and plates, $T$. harzianum WT6 consistently being associated with the lowest number of sclerotia. There was no effect of time of application of $P$. oligandrum except on tomato tissue but $G$. roseum and $T$. harzianum (IMI 275950) consistently showed an effect of time of application on all three tissues. The greatest number of sclerotia were produced when the $T$. harzianum isolates and $G$. roseum were applied after the $S$. sclerotiorum (treatment C, Table 1). A similar pattern was shown for the sclerotia produced on the plate, but due to the large number of zero values, the plate analyses must be treated with some caution.

In order to ascertain whether the system could be streamlined to enable quicker assessment of effect of antagonists, the data for production of sclerotia were subsequently analysed on the basis of presence or absence of sclerotia on the tissue pieces (Table 2). To facilitate analysis, the control group was omitted as it was indistinguishable from the $P$. oligandrum treament and the remaining $5 \times 3$ factorial was analysed for each tissue type using a binomial analysis with a logit link. $G$. roseum and all $T$. harzianum isolates caused a significant reduction in the incidence of sclerotia on all tissues, with the $T$. harzianum isolates causing the greatest reduction on celery and lettuce (Table $2 a$ ). On tomato, $G$. roseum decreased the incidence of sclerotia almost as much as $T$. harzianum WT6, which was consistently associated with the lowest incidence of sclerotia on all tissues. Differences between time of application were significant for all three tissue types (Table $2 b$ ). Treatment B (simultaneous application of antagonist and $S$. sclerotiorum) consistently gave the lowest incidence of sclerotia while treatment C (antagonist applied after $S$. sclerotiorum) gave the highest. 
Table 3. Incidence of recovery of antagonists from distal end of plant tissue

\begin{tabular}{|c|c|c|c|c|c|c|}
\hline & \multicolumn{4}{|c|}{$\begin{array}{c}\begin{array}{c}\text { Incidence of recovery } \\
\text { (out of } 9 \text { ) }\end{array} \\
\text { (out }\end{array}$} & \multicolumn{2}{|c|}{$\begin{array}{l}\text { Significance of } \\
\text { differences }\end{array}$} \\
\hline & \multirow[b]{2}{*}{ Control $†$} & \multicolumn{3}{|c|}{ Treatment $\ddagger$} & \multirow[b]{2}{*}{$\begin{array}{l}\text { Control v. } \\
\text { antag. } \|\end{array}$} & \multirow[b]{2}{*}{$\begin{array}{l}\text { Between } \\
\text { treatments }\end{array}$} \\
\hline & & A & B & $\overrightarrow{\mathrm{C}}$ & & \\
\hline \multicolumn{7}{|l|}{ Celery } \\
\hline$P$. oligandrum & 0 & 0 & 0 & 0 & & \\
\hline G. roseum & 9 & 9 & 9 & 9 & & \\
\hline T. harzianum IMI 298374 & 4 & 4 & 8 & 9 & NS & $* * *$ \\
\hline T. harzianum IMI 275950 & 3 & 3 & 5 & 9 & NS & *** \\
\hline T. harzianum WT6 & 4 & 4 & 3 & 6 & NS & $* * *$ \\
\hline \multicolumn{7}{|l|}{ Lettuce } \\
\hline$P$. oligandrum & 0 & 0 & 0 & 0 & & \\
\hline G. roseum & 9 & 9 & 9 & 9 & & \\
\hline T. harzianum IMI 298374 & 8 & 9 & 9 & 9 & & \\
\hline T. harzianum IMI 275950 & 9 & 9 & 9 & 9 & & \\
\hline$T$. harzianum WT6 & 9 & 9 & 9 & 9 & & \\
\hline \multicolumn{7}{|l|}{ Tomato } \\
\hline P. oligandrum & 0 & 0 & 0 & 0 & & \\
\hline G. roseum & 8 & 9 & 9 & 9 & & \\
\hline T. harzianum IMI 298374 & 1 & 3 & 6 & 8 & * & $* * *$ \\
\hline T. harzianum IMI 275950 & 1 & 8 & 5 & 1 & $*$ & $* * *$ \\
\hline T. harzianum WT6 & 4 & 8 & 7 & 8 & $*$ & $* * *$ \\
\hline
\end{tabular}

$\dagger$ Antagonist without $S$. sclerotiorum.

$\ddagger$ Treatments A, B and C have antagonist applied $24 \mathrm{~h}$ before, simultaneously with, or $24 \mathrm{~h}$ after $S$. sclerotionum respectively.

$\$$ Effects are not significant (NS) or significant at the $5 \%(*)$ or $0.1 \%(* * *)$ level respectively. A blank space indicates 'not tested'.

\|The comparison is for control v. mean of treatments A, B and C.

\section{Recovery of antagonists from distal end of tissue}

The incidence of recovery of antagonists from the distal ends of tissue pieces is given in Table 3. $P$. oligandrum failed to reach the distal end of all tissues whereas $G$. roseum (almost) always succeeded. This latter feature was similarly exhibited by all the $T$. harzianum isolates on lettuce. For this reason, all these data were excluded from subsequent analysis, leaving two $3 \times 4$ matrices for celery and tomato. These were examined by using a simple binomial analysis relating the response (out of 9) to the factors of antagonist type and time of application (treatments A, B and C). For celery there was a significant effect of time of application but no difference between the mean of the antagonist type and the respective controls nor any interaction. Early application of the antagonist (treatment A) was similar to the control, with progressively later application leading to greater recovery. In tomato, significant effects were found between the controls and the mean of the antagonist types as well as between the times of application. An interaction was found between antagonist type and time of application but $T$. harzianum WT6 was regularly recovered at the highest incidence at all treatment times.

\section{DISCUSSION}

Consistent effects of the antagonists were shown on all three tissues examined. Irrespective of time of application, $P$. oligandrum had no effect on the number of sclerotia formed except on tomato tissue. When the results were expressed as incidence of sclerotia a similar pattern was found and the tomato effect was not detected. $P$. oligandrum had no ability to grow through any tissue. In contrast, $G$. roseum and the $T$. harzianum isolates significantly reduced the number and incidence of sclerotia formed on all tissues and showed marked ability to grow through 
tissue from cut surfaces. This was particularly so with $G$. roseum. For $G$. roseum and $T$. harzianum isolates, treatment $C$ (when the antagonist was applied after $S$. sclerotiorum) gave the greatest number and incidence of sclerotia produced, indicating that pretreatment with antagonists was beneficial in preventing sclerotium formation.

On all three tissues the presence of $T$. harzianum WT6 resulted in the lowest incidence of sclerotia, and this isolate was potentially the most effective biocontrol agent tested, particularly as it has some ability to enter the plant tissue. However, if occupation of residues from cut surfaces is of greater importance then $G$. roseum could be of more value. Significantly, after treatment of intact lettuce leaves with spore sprays of all these fungi no morphological or pathological symptoms were noted (unpublished observations), implying the need for cut or damaged tissue for entry.

The pattern of behaviour of the antagonists observed on these tissue pieces agrees well with the known ecological properties of each of the fungi. $P$. oligandrum has little or no ability to infect higher plants (Deacon \& Henry, 1978) and survives in soil as long-lived oospores with the capability to act as a mycoparasitic biological control agent of plant-pathogenic Pythium spp. (Al-Hamdani et al., 1983). Interestingly, it does have the ability to parasitize mycelium of $S$. sclerotiorum on agar (unpublished observations) but appears of little use as a biocontrol agent of $S$. sclerotiorum from this system. Both $G$. roseum and $T$. harzianum can behave as mycoparasites and biocontrol agents of a range of plant pathogens and can survive in the soil as spores. They grow rapidly when substrates such as plant debris become available and exhibit little ability to infect intact plants (Papavizas, 1985). It may well be that these fungi could enter cut surfaces of plant residues and use them as a food source after harvest, particularly if normal resistance mechanisms were impaired by senescence in the residue. Of note here is the recent report that $G$. roseum has been found as a non-pathogenic systemic parasite of soybeans, particularly of roots and older parts of the stem (Mueller \& Sinclair, 1986), but the method of entry into the soybean is not known.

Other workers have treated sclerotia of $S$. sclerotiorum derived from agar culture or autoclaved tissue pieces with putative antagonists as a screen for biocontrol activity (e.g. Makkonen \& Pohjakallio, 1960; Mueller et al., 1985) as this provides uncontaminated, uniform sclerotia. However, sclerotia produced in culture differ in physiological properties and resistance to biocontrol agents from those produced on living material (Turner \& Tribe, 1976; Trutmann et al., 1980; Coley-Smith, 1985). Thus, this is the first example of antagonist tests utilizing sclerotia formed from initially living systems and as such it may give more reliable results.

The system described here also has the potential to give information on the viability of the sclerotia produced. Preliminary assessments of apothecial formation and sclerotium contamination were technically easy and simply carried out on the low numbers of sclerotia produced in these systems (unpublished observations). However, for meaningful statistical analyses to be obtained, greater numbers of sclerotia would have to be used in the future.

Overall the system appears to provide a simple, rapid and reproducible method of screening antagonists for their ability to inhibit sclerotium formation in plant tissue. The use of the incidence of sclerotia (Table 2) as a guide to efficacy appears particularly valuable.

I thank Sarah Molyneux for technical assistance and John Fenlon for the statistical analyses.

\section{REFERENCES}

Al-Hamdani, A. M., Lutchmeah, R. S. \& CoOke, R. C. (1983). Biological control of Pythium ultimuminduced damping-off by treating cress seed with the mycoparasite Pythium oligandrum. Plant Pathology 32, 449-454.

Coley-Smith, J. R. (1985). Methods for the production and use of sclerotia of Sclerotium cepivorum in field germination studies. Plant Pathology 34, 380384.
Coley-Smith, J. R. \& Cooke, R. C. (1971). Survival and germination of fungal sclerotia. Annual Review of Phytopathology 9, 65-92.

Deacon, J. N. (1976). Studies on Pythium oligandrum, an aggressive parasite of other fungi. Transactions of the British Mycological Society 66, 383-391.

DeACon, J. N. \& HeNRY, C. M. (1978). Mycoparasitism by Pythium oligandrum and $P$. acanthicum. Soil Biology and Biochemistry 10, 409-415. 
Dreschler, C. (1943). Antagonism and parasitism among some oomycetes associated with root rot. Journal of the Washington Academy of Sciences 33, 21-28.

Fravel, D. R., Marois, J. J., Lumsden, R. D. \& ConNICK, W. J. (1985). Encapsulation of potential biocontrol agents in an alginate-clay matrix. Phytopathology 75, 774-777.

HARPER, S. H. T. \& LYNCH, J. M. (1984). Nitrogen fixation by cellulolytic communities of aerobicanaerobic interfaces in straw. Journal of Applied Bacteriology 57, 131-137.

Hubbard, J. P., Harman, G. E. \& Hadar, Y. (1983). Effect of soilborne Pseudomonas spp. on the biological control agent, Trichoderma hamatum, on pea seeds. Phytopathology 73, 655-659.

Lewis, J. A. \& Papavizas, G. C. (1985). Characteristics of alginate pellets formulated with Trichoderma and Gliocladium and their effect on the proliferation of the fungi in soil. Plant Pathology 34, 571-577.

LOPER, J. E., HAACK, C. \& SCHROTH, M. N. (1985). Population dynamics of soil pseudomonads in the rhizosphere of potato (Solanum tuberosum L.). Applied and Environmental Microbiology 49, 416-422.

LUTCHMEAH, R. S. \& COOKE, R. C. (1984). Aspects of antagonism by the mycoparasite Pythium oligandrum. Transactions of the British Mycological Society 83, 696-700.

LYNCH, J. M. \& EBBEN, M. H. (1986). The use of microorganisms to control plant disease. Journal of Applied Bacteriology Symposium Supplement 115S-126S.

McCullagh, P. \& Nelder, J. A. (1983). Generalized Linear Models. London: Chapman \& Hall.

Makkonen, R. \& Pohjakallio, O. (1960). On the parasites attacking the sclerotia of some fungi pathogenic to higher plants and on the resistance of these sclerotia to their parasites. Acta agriculturae scandinavica 10, 105-126.

Mueller, J. D. \& Sinclair, J. B. (1986). Occurrence and role of Gliocladium roseum in field-grown soybeans in Illinois. Transactions of the British Mycological Society 86, 677-680.

Mueller, J. D., Cline, M. D., Sinclair, J. B. \& JACOBSEN, B. J. (1985). An in vitro test for evaluating efficacy of mycoparasites on sclerotia of Sclerotinia sclerotiorum. Plant Disease 69, 584-587.

PaPAVIZAs, G. C. (1985). Trichoderma and Gliocladium: biology, ecology and potential for biocontrol. Annual Review of Phytopathology 23, 23-54.

Papavizas, G. C. \& Lumsden, R. D. (1982). Improved medium for isolation of Trichoderma spp. from soil. Plant Disease 66, 1019-1020.

RISHBETH, J. (1975). Stump inoculation: a biological control of Fomes annosus. In Biology and Control of Soil-borne Plant Pathogens, pp. 158-162. Edited by G. W. Bruehl. St Paul, Minnesota: American Phytopathological Society.

Suslow, T. V. \& SCHROTH, M. N. (1982). Rhizobacteria of sugar beets: effects of seed application and root colonization on yield. Phytopathology 72, 199206.

Trutmann, P., Keane, P. J. \& Merriman, P. R. (1980). Reduction of sclerotial inoculum of Sclerotinia sclerotiorum with Coniothyrium minitans. Soil Biology and Biochemistry 12, 461-465.

TURner, G. J. \& TRIBE, H. T. (1976). On Coniothyrium minitans and its parasitism of Sclerotinia species. Transactions of the British Mycological Society 66, 97105.

VAN DEN BOOgert, P. H. J. F. \& JAGer, G. (1984). Biological control of Rhizoctonia solani on potatoes by antagonists. 3. Inoculation of seed potatoes with different fungi. Netherlands Journal of Plant Pathology 90, 117-126.

VESELÝ, D. \& HeJdÁNEK, S. (1984). Microbial relations of Pythium oligandrum and problems in use of this organism for the biological control of damping-off in sugar beet. Zentralblatt für Mikrobiologie 139, 257265. 